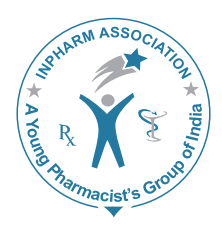

\title{
JVP
}

\section{Pharmacokinetic Evaluation of Paclitaxel in South Indian Cancer Patients: A Prospective Study}

\author{
Vasantha J, Kannan G, Goud T, Palani T, Vanitha R, Anitha R', \\ Priya $\mathrm{JMM}^{1}$ \\ Department of Pharmacy Practice, Faculty of Pharmacy, Sri Ramachandra University, \\ ${ }^{1}$ Medical Oncologists, Sri Ramachandra Hospital, Porur, Chennai, Tamil Nadu, India \\ Address for correspondence: Dr. Vasantha Janardhan; E-mail: vasajan2001 @ hotmail.com
}

\begin{abstract}
Paclitaxel is a promising drug in the treatment of different solid tumors. It exhibits nonlinear pharmacokinetics, particularly when administered as a constant rate infusion for shorter duration (e.g., $3 \mathrm{~h}$ ). Because of the nonlinearity, relatively small changes in dose may lead to large changes in peak plasma concentration and total drug exposure. The study was conducted to evaluate the pharmacokinetics of different doses of paclitaxel administered intravenously as an infusion. A prospective study was conducted in 23 cancer patients aged between 28 and 74 years, treated with paclitaxel $\left(130,200,230\right.$, and $\left.260 \mathrm{mg} / \mathrm{m}^{2}\right)$ over $3 \mathrm{~h}$ as constant rate infusion. Plasma samples were collected from all patients at 0,1 , and $3 \mathrm{~h}$ and for five patients at 5 and $13 \mathrm{~h}$ and paclitaxel concentrations were determined using high-performance liquid chromatography method. The overall mean clearance was found to be $47.5847 \pm 142.028 \mathrm{l} / \mathrm{h}$; the mean volume of distribution was $142.028 \pm 73.438 \mathrm{l}$; mean elimination rate constant was $0.336 \pm 0.002 / \mathrm{h}$; mean half-life was $2.086 \pm 0.009 \mathrm{~h}$; mean area under the curve (AUC) was $5.5917 \pm 2.707 \mathrm{mg} / \mathrm{ml} \mathrm{h}^{*}$; and the mean of mean residence time was $2.980 \pm 0.0131 \mathrm{~h}$. Paclitaxel showed nonlinear kinetics and the pharmacokinetic parameters calculated were similar to those quoted in the literature. The peak plasma concentration at $130 \mathrm{mg}$ dose level was $2 \mu / \mathrm{ml}$, but an increase in dose was not associated with proportional increase in plasma concentration. No significant difference was found between pharmacokinetic parameters such as clearance, volume of distribution, and AUC at different dose levels.
\end{abstract}

Key words: Non-linear, pharmacokinetics, plasma concentrations, optimization, taxane

\section{INTRODUCTION}

Paclitaxel is a taxane, produced semisynthetically from a precursor found in the leaves of Taxus baccata. ${ }^{[1]}$

\begin{tabular}{|l|l|}
\hline \multicolumn{2}{|c|}{ Access this article online } \\
\hline Quick Response Code: & \\
\hline & Website: \\
\hline & www.jyoungpharm.in \\
\hline & DOI: \\
\hline
\end{tabular}

Paclitaxel is a potent anticancer drug. ${ }^{[2,3]}$ Paclitaxel, with its unique mechanism of action as an inducer of tubulin polymerization, has demonstrated impressive clinical antitumor activity in patients with breast, lung, head, neck, and advanced platinum-refractory ovarian carcinoma. It appears to be one of the most promising agents for the first- or second-line chemotherapy of solid tumors. ${ }^{[4]}$

Paclitaxel exhibits nonlinear pharmacokinetics, particularly when the drug is administered over shorter periods of infusion $(3 \mathrm{~h})$. Both saturable distribution and elimination 
contribute to the nonlinear disposition of paclitaxel. Because of the nonlinearity of its pharmacokinetics, relatively small changes in dose may lead to large changes in peak plasma concentrations and total drug exposure. Following intravenous administration, paclitaxel is widely distributed into body fluids and tissues. It has a large volume of distribution that appears to be affected by dose and duration of infusion. ${ }^{[5-9]}$

Paclitaxel is extensively metabolized in the liver. Metabolism to its major metabolite, 6a-hydroxypaclitaxel, is mediated by cytochrome P-450 isoenzyme CYP2C8, while metabolism to two of its minor metabolites, 3'-p-hydroxypaclitaxel and 6a, 3'-p-dihydroxypaclitaxel, is catalyzed by CYP3A4.35. Paclitaxel and its metabolites are excreted principally in the feces via biliary elimination. Both a reduction in the clearance and an overproportional increase in peak plasma concentration (Cmax) of paclitaxel are observed with increasing dosages indicative that both drug elimination and distribution were affected. ${ }^{[10]}$

Safety and efficacy of paclitaxel have been studied extensively. ${ }^{[11]}$ However, its complete pharmacokinetic profile in humans has not yet been fully understood. With this in background, pharmacokinetics of paclitaxel has been studied with the objectives of optimizing the dose to achieve desired plateau plasma-drug concentration, to maximize response and reduce toxicity of drug, and to learn what factors affect plasma concentrations in the study population.

\section{MATERIALS AND METHODS}

A prospective study was conducted between September 2008 and March 2009, in the medical oncology wards of a 1675-bedded tertiary care teaching hospital in South India, with the approval of the Institutional Ethics Committee (IEC/08/SEP/68/33) and the consent of the study participants. Patients above 18 years of age, with histologically confirmed malignancy and treated with paclitaxel were enrolled in this study.

A detailed data of all the patients were collected which included demographics (age, sex, weight, and height) disease status, smoking habits, alcoholic consumption, family history, co morbidities (Cardiovascular, renal, and hepatic diseases), and medications taken along with paclitaxel.

The patients were administered paclitaxel at the doses of $130,200,230$, and $260 \mathrm{mg} / \mathrm{m}^{2}$ intravenously as constant rate infusion over $3 \mathrm{~h}$. Vials containing $6 \mathrm{mg} / \mathrm{ml}$ of paclitaxel supplied by Feron life sciences (Pacliron), Intas biopharmaceuticals (Cytax), and Macmoham Pharma Ltd. (Amtax) were used for this study. After $3 \mathrm{~h}$ of paclitaxel infusion, patients were administered intravenous saline for $3 \mathrm{~h}$. The saline was stopped, and patients were given either one or two of the following drugs cisplatin, carboplatin, and 5-fluorouracil. The patients were also treated with dexamethasone $8 \mathrm{mg}$ intravenous, ranitidine $50 \mathrm{mg}$ intravenous, diphenhydramine $50 \mathrm{mg}$ intramuscular, and palanosetran $0.25 \mathrm{mg}$ in $100 \mathrm{ml}$ of saline over $30 \mathrm{~min}$ before starting paclitaxel therapy.

Heparinized blood samples were collected from the patients before starting paclitaxel infusion $(0 \mathrm{~h})$ and at the time intervals of 1 and $3 \mathrm{~h}$ for all patients; 5 and $13 \mathrm{~h}$ for five patients and were stored at $-80^{\circ} \mathrm{C}$. The extraction of paclitaxel from the biological matrix was carried out by using protein precipitation method.

The plasma concentrations of paclitaxel at various time intervals were determined using high-performance liquid chromatography (HPLC), and pharmacokinetic parameters of paclitaxel at different dose levels were evaluated.

Estimation of plasma concentrations of paclitaxel by HPLC

Paclitaxel estimations by HPLC were conducted at Dr. T M A Pai Bioavailability Center, Manipal College of Pharmaceutical Sciences, Manipal. The estimations were carried out by adapting a validated method stated in "Analytical Methods Validation: Bioavailability, Bioequivalence and Pharmacokinetic Studies," ${ }^{[12]}$ with minor modification as stated in the study done by Alex Sparreboom. ${ }^{[13]}$

\section{Materials}

1. Paclitaxel: Natco Pharma Ltd. (standard)

2. Celecoxib: Dr. Reddy's Laboratories (Internal standard)

3. Acetonitrile (HPLC grade): E-Merck (India) Limited, Mumbai.

4. Methanol (HPLC grade): E-Merck (India) Limited, Mumbai.

5. Glacial acetic acid (GR grade): E-Merck (India) Limited, Mumbai.

6. Eppandorff tubes $(2 \mathrm{ml})$ : Tarsons Products Pvt. Ltd., Kolkata.

7. Centrifuge tubes $(15 \mathrm{ml})$ : Tarsons Products Pvt. Ltd., Kolkata.

8. Micro tips ( $1 \mathrm{ml}, 0.2 \mathrm{ml}$, and10 $\mu \mathrm{l})$ : Tarsons Products Pvt. Ltd., Kolkata 


\section{Equipment}

The HPLC system with LC-2010HT HPLC Spectrophotometer detector (Shimadzu, Kyoto, Japan). Synergi 4u Fusion-RP 80A, 5 mm, $250 \times 4.6$ mm, SS C18 column (Denali) was used for the analysis.

Chromatographic conditions

$\begin{array}{ll}\text { Mobile phase } & : \text { Acetonitrile: Acetate buffer (4.5) } \\ & \text { mixture }(60: 40) \\ \text { Flow rate } & : 1 \mathrm{ml} / \mathrm{min} \\ \text { Pressure } & : 100 \mathrm{~kg} . \mathrm{f} / \mathrm{cm}^{2} \\ \text { Injection volume } & : 50 \mu \mathrm{l} \\ \text { Column temperature } & : \text { Room temperature } \\ \text { UV detection at } & : 230 \mathrm{~nm}\end{array}$

Preparation of mobile phase

Mobile phase consisting of acetonitrile: Acetate buffer 4.5 (60:40) was prepared by addition of specified quantities and mixed thoroughly. Mobile phase was degassed and used for the HPLC analysis; $1.0 \mathrm{ml} / \mathrm{min}$ flow rate was maintained throughout the analysis. The eluent was monitored using UV detector set at $230 \mathrm{~nm}$.

\section{Preparation of standard solution}

Stock solutions of $1 \mathrm{mg} / \mathrm{ml}$ of paclitaxel were prepared in double distilled water. These solutions were further diluted with double distilled water to produce working stock solutions of $100 ; 10 \mu \mathrm{g} / \mathrm{ml}$. All solutions were stored at $-4^{\circ} \mathrm{C}$.

Preparation of ammonium acetate buffer ( $\mathrm{pH} 4.5)$

About $1.44 \mathrm{~g}$ of ammonium acetate was weighed accurately and dissolved in $1000 \mathrm{ml}$ of Millipore water. The $\mathrm{pH}$ was adjusted using glacial acetic acid.

\section{Extraction procedure}

The extraction of paclitaxel from the biological matrix was carried out by using protein precipitation method. This method was carried out by using precipitating agent acetonitrile. One hundred microliters of paclitaxel containing human plasma sample was taken into $1.5 \mathrm{ml}$ of centrifuge tubes and $10 \mu \mathrm{l}$ of $100 \mu \mathrm{g} / \mathrm{ml}$ celecoxib was added as internal standard and vertexed for $5 \mathrm{~min}$, then it was centrifuged at 10,000 $\mathrm{rpm}$ for $10 \mathrm{~min}$, and the clear supernatant (around $50 \mu \mathrm{l}$ each) was transferred into HPLC vials and was subjected to HPLC analysis.
Preparation of calibration curve of paclitaxel in human plasma

Plasma used for plotting the standard graph was obtained from healthy volunteers. Different concentrations $(50,100,200,500,1000,2500,5000$, and 10,000 ng/ml) of paclitaxel along with a constant concentration of internal standard $(100 \mu \mathrm{g} / \mathrm{ml})$ in plasma were prepared for calibration curve. The samples were treated as above for extraction. The extracted sample $(50 \mu \mathrm{l})$ was injected and eluted with mobile phase. Column solvents were degassed before use. The peak ratios of responses of standard drug (paclitaxel) and internal standard (celecoxib $100 \mu \mathrm{g}$ ) were noted down. The peak ratios of responses multiplied by 1000 , obtained at different concentrations of the drug, were plotted against the concentrations of drug. The slope of the plot determined by the method of least square regression analysis was used to calculate the paclitaxel concentration in the unknown sample [Table 1]. The linearity was found to be in the range $50-10,000 \mathrm{ng} / \mathrm{ml}$ of paclitaxel in plasma, with a mean regression correlation coefficient of $\left(\mathrm{r}^{2}=0.9996\right)$ in plasma matrix [Figure 1]. The lowest limit of quantification was established at $50 \mathrm{ng} / \mathrm{ml}$ and the upper limit of quantification at $10,000 \mathrm{ng} / \mathrm{ml}$, both the mean percentage deviation and the between run precision were less than $5 \%$. The retention times of paclitaxel and celecoxib were 6.7 and $10.6 \mathrm{~min}$, respectively.

Analysis of the blood samples

Blood samples were run along with quality controls, and concentrations were determined from calibration curve. The pharmacokinetic parameters were estimated with manual calculators using the following equations. ${ }^{[8]}$

1. Total clearance:

Clearance $=$ dosing rate $/$ Css (peak plasma concentration at steady state); units $=1 / \mathrm{h}$

2. Volume of distribution:

Table 1: Linearity of paclitaxel and internal standard at various concentrations

\begin{tabular}{lccc}
\hline $\begin{array}{l}\text { Drug concentrations } \\
(\mathbf{n g} / \mathrm{ml})\end{array}$ & $\begin{array}{c}\text { Drug } \\
\text { response }\end{array}$ & $\begin{array}{c}\text { Internal } \\
\text { standard }\end{array}$ & $\begin{array}{c}\text { Peak } \\
\text { ratio }\end{array}$ \\
\hline 50 & 3,923 & 235,089 & 0.01 \\
100 & 8,874 & 229,044 & 0.04 \\
200 & 23,504 & 231,579 & 0.10 \\
500 & 43,517 & 247,732 & 0.18 \\
1,000 & 95,886 & 226,548 & 0.42 \\
2,500 & 216,643 & 236,578 & 0.92 \\
5,000 & 435,636 & 221,545 & 1.96 \\
10,000 & 895,955 & 225,074 & 3.85 \\
\hline
\end{tabular}

Journal of Young Pharmacists Vol 3 / No 4 


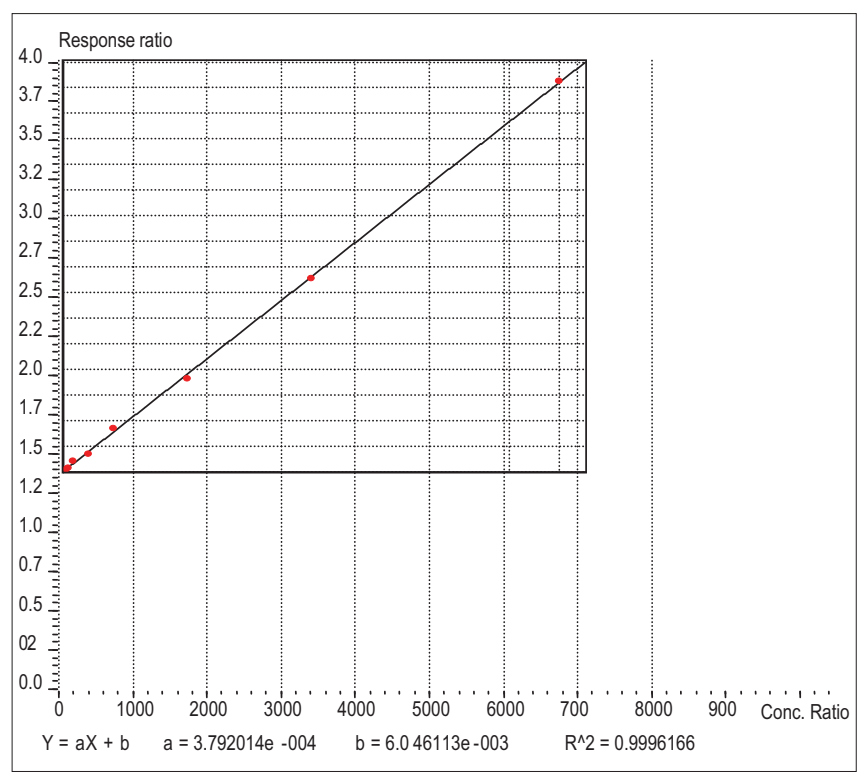

Figure 1: Linearity plot of paclitaxel

Volume of distribution

$$
\begin{aligned}
&= \frac{\text { amount present in the body }}{\text { Css (peak plasma concentration at steady state) }} ; \\
& \text { units }=1
\end{aligned}
$$

3. Elimination rate constant:

Elimination rate constant $=$ clearance/volume of distribution; units $=\min ^{-1}$

4. Half-life:

Half-life $\left(t^{1} / 2\right)=0.693 / \mathrm{K}$; units $=$ hour or $\min$.

5. Area under curve:

Area under curve $=$ clearance $/$ volume of distribution; units $=\mathrm{mg} / \mathrm{ml}$.

6. Mean residence time (MRT):

MRT $=$ volume of distribution/clearance $;$ units $=\mathrm{h}$

\section{RESULTS}

A total of 23 cancer patients (8 males and 15 females) were enrolled in this study. The baseline characteristics of the study population are shown in Table 2 . The mean age of the patients was 47 years (range 28-71 years) and the mean body surface area was $1.54 \mathrm{~m}^{2}$ (range $\left.1.28-1.94 \mathrm{~m}^{2}\right)$. Majority of the patients $(n=10 ; 43.48 \%)$ had breast cancer.

\section{Estimation of plasma concentration of paclitaxel}

The study adopted a validated HPLC assay for the determination of the concentration of paclitaxel in plasma. The blank, standard, and test chromatograms (plasma) are shown in Figures 2 and 3. Paclitaxel was given as a constant
Table 2: Baseline characteristics of study population

\begin{tabular}{lcc}
\hline Patient characteristics $(\mathbf{n = 2 3 )}$ & Mean $(\mathbf{\%})$ & Range \\
\hline Males/females & $8 / 15$ & - \\
Age (years) & 47 & $28-71$ \\
Body surface area $\left(\mathrm{m}^{2}\right)$ & 1.54 & $1.28-1.94$ \\
Body weight $(\mathrm{kg})$ & 57 & $40-77$ \\
Serum creatinine $(\mathrm{mg} / \mathrm{dl})$ & 0.85 & $0.4-1.3$ \\
Dose $(\mathrm{mg})$ & 205 & $130-260$ \\
Cancer type & & \\
Breast & $10(43.47)$ & \\
Stomach & $3(13.04)$ & \\
Lung & $1(3.85)$ & \\
Ovarian & $3(13.04)$ & \\
Esophagus & $1(3.85)$ & \\
Pancreas & $1(3.85)$ & \\
Nasopharyngeal & $2(8.7)$ & \\
Cervix & $2(8.7)$ & \\
\hline
\end{tabular}

rate intravenous infusion for $3 \mathrm{~h}$ only and then stopped; hence peak concentration and steady state were achieved at $3 \mathrm{~h}$ and subsequently dropped.

\section{Pharmacokinetic parameters}

The pharmacokinetic parameters of different doses of paclitaxel in the study population are shown in Table 3. The overall mean clearance was found to be $47.5847 \pm 142.0281 / \mathrm{h}$; the mean volume of distribution was $142.028 \pm 73.438 \mathrm{l}$; mean elimination rate constant was $0.336 \pm 0.002$ /hour; mean half-life was $2.086 \pm 0.009 \mathrm{~h}$; mean area under the curve (AUC) was $5.5917 \pm 2.707 \mathrm{mg} / \mathrm{ml} * \mathrm{~h}$; the mean of MRT was $2.980 \pm 0.0131 \mathrm{~h}$. The mean values of the pharmacokinetic parameters (clearance, volume of distribution, elimination rate constant, half-life, AUC, and MRT) for doses of paclitaxel at 130, 230, 200, and $260 \mathrm{mg}$ of constant infusion for $3 \mathrm{~h}$ were given as in Table 3 .

Statistical analysis

The results were statistically analyzed by analysis of variance (ANOVA). The age of the patients was correlated with mean volume of distribution [Table 4]. The volume of distribution decreased with increase in age but was not statistically significant $(F=0.09 ; P=0.914)$. There was a significant increase in volume of distribution as body weight increased $(F=1.103 ; P=0.351)$ as shown in Table 5. The body surface area $(F=0.332 ; P=0.802$ and serum creatinine levels $(F=0.08 ; P=0.780)$ did not have a significant effect on mean volume of distribution, and the patients with serum creatinine values $>1.0$ showed an increased volume of distribution [Tables 6 and 7]. Clearance was directly proportional to volume of distribution $(F=1.22 ; P=1.89)$ but was not statistically significant [Table 8]. 
Table 3: Mean values of paclitaxel pharmacokinetic parameters at different doses

\begin{tabular}{|c|c|c|c|c|c|c|c|c|}
\hline $\begin{array}{l}\text { Dose } \\
\left(\mathrm{mg} / \mathrm{m}^{2}\right)\end{array}$ & $\begin{array}{l}\text { No. of patients } \\
(N=\mathbf{2 3})\end{array}$ & $\begin{array}{c}\text { Mean } \\
\text { Css (mg) }\end{array}$ & $\begin{array}{c}\text { Mean } \\
\text { CL (l/h) }\end{array}$ & $\begin{array}{l}\text { Mean } \\
\text { Vd (I) }\end{array}$ & $\begin{array}{l}\text { Mean } \\
\text { K }(/ \mathbf{h})\end{array}$ & $\begin{array}{l}\text { Mean } \\
T_{1 / 2}(\mathrm{~h})\end{array}$ & $\begin{array}{c}\text { Mean AUC } \\
(\mathrm{mg} / \mathrm{ml} . \mathrm{h})\end{array}$ & $\begin{array}{c}\text { Mean } \\
\text { MRT (h) }\end{array}$ \\
\hline 130 & 5 & 0.003 & 8.56 & 54.84 & 0.34 & 2.09 & 8.52 & 2.95 \\
\hline 200 & 6 & 0.002 & 34.65 & 103.44 & 0.34 & 2.09 & 6.17 & 2.99 \\
\hline 230 & 3 & 0.001 & 54.73 & 163.48 & 0.34 & 2.09 & 4.33 & 2.99 \\
\hline \multirow[t]{3}{*}{260} & 9 & 0.001 & 69.95 & 209.04 & 0.34 & 2.09 & 3.99 & 2.99 \\
\hline & & Mean & 47.58 & 142.03 & 0.34 & 2.09 & 5.59 & 2.98 \\
\hline & & $S D$ & 24.52 & 73.44 & 0.00 & 0.00 & 2.71 & 0.014 \\
\hline
\end{tabular}

Table 4: Age versus mean volume of distribution

\begin{tabular}{lccc}
\hline Age (years) $(n=23)$ & Mean Vd (l) & Standard deviation & ANOVA \\
\hline$<40(n=6)$ & 153 & \pm 81.04 & $F=0.09$ \\
$40-60(n=16)$ & 138 & \pm 75.16 & $P=0.914$ \\
$>60(n=1)$ & 132 & \pm 73.43 & \\
\hline
\end{tabular}

Table 5: Weight versus mean volume of distribution

\begin{tabular}{lccc}
\hline Weight $(\mathrm{kg})(n=23)$ & Mean Vd (l) & Standard deviation & ANOVA \\
\hline $40-50(n=6)$ & 105 & \pm 47.17 & $F=1.103$ \\
$50-60(n=9)$ & 147 & \pm 99.65 & $P=0.351 *$ \\
$>60(n=8)$ & 163 & \pm 48.24 & \\
\hline *Significant. & & &
\end{tabular}

Table 6: Body surface area versus mean volume of distribution

\begin{tabular}{lccc}
\hline $\begin{array}{l}\text { Body surface area }\left(\mathrm{m}^{2}\right) \\
(N=23)\end{array}$ & Mean Vd $(\mathbf{l})$ & $\begin{array}{l}\text { Standard } \\
\text { deviation }\end{array}$ & ANOVA \\
\hline $1.2-1.4(n=6)$ & 133 & \pm 61.1 & $F=0.332$ \\
$>1.4-1.6(n=8)$ & 129 & \pm 87.9 & $P=0.802$ \\
$>1.6-1.8(n=8)$ & 163 & \pm 75.5 & \\
$>1.8-2(n=1)$ & 118 & \pm 73.4 & \\
\hline
\end{tabular}

Table 7: Serum creatinine versus mean volume of distribution

\begin{tabular}{lccc}
\hline $\begin{array}{l}\text { Serum creatinine } \\
(\mathbf{m g} / \mathbf{d l})(N=\mathbf{2 3})\end{array}$ & Mean Vd (l) & $\begin{array}{l}\text { Standard } \\
\text { deviation }\end{array}$ & ANOVA \\
\hline$<1.2(n=17)$ & 130 & \pm 71.89 & $F=0.080$ \\
$>1.2(n=6)$ & 173 & \pm 74.64 & $P=0.780$ \\
\hline
\end{tabular}

Table 8: Clearance versus mean volume of distribution

\begin{tabular}{lccc}
\hline $\begin{array}{l}\text { Clearance (Liters/Hour) } \\
(N=23)\end{array}$ & Mean Vd (l) & $\begin{array}{l}\text { Standard } \\
\text { deviation }\end{array}$ & ANOVA \\
\hline$<40(n=10)$ & 76 & \pm 35.00 & $F=1.22$ \\
$40-60(n=4)$ & 125 & \pm 5.04 & $P=1.89$ \\
$>60(n=9)$ & 221 & \pm 29.07 & \\
\hline
\end{tabular}

\section{DISCUSSION}

Paclitaxel is a promising drug in the treatment of different solid tumors. In our hospital, 3-h infusion is used at four dose levels 130, 200, 230, and $260 \mathrm{mg}$. This study was undertaken with the aim of assessing pharmacokinetic parameters in constant rate intravenous infusion model at different dose levels. Several studies have shown that

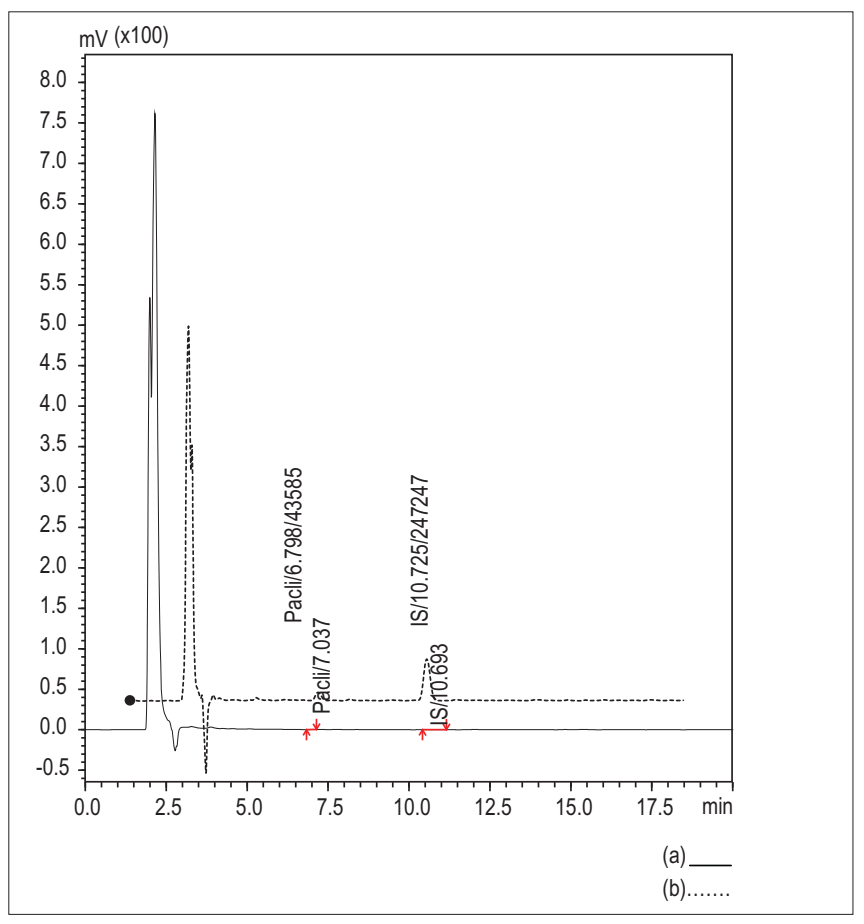

Figure 2: HPLC chromatograms (a) chromatogram of standards; (b) chromatogram of human plasma (healthy volunteers)

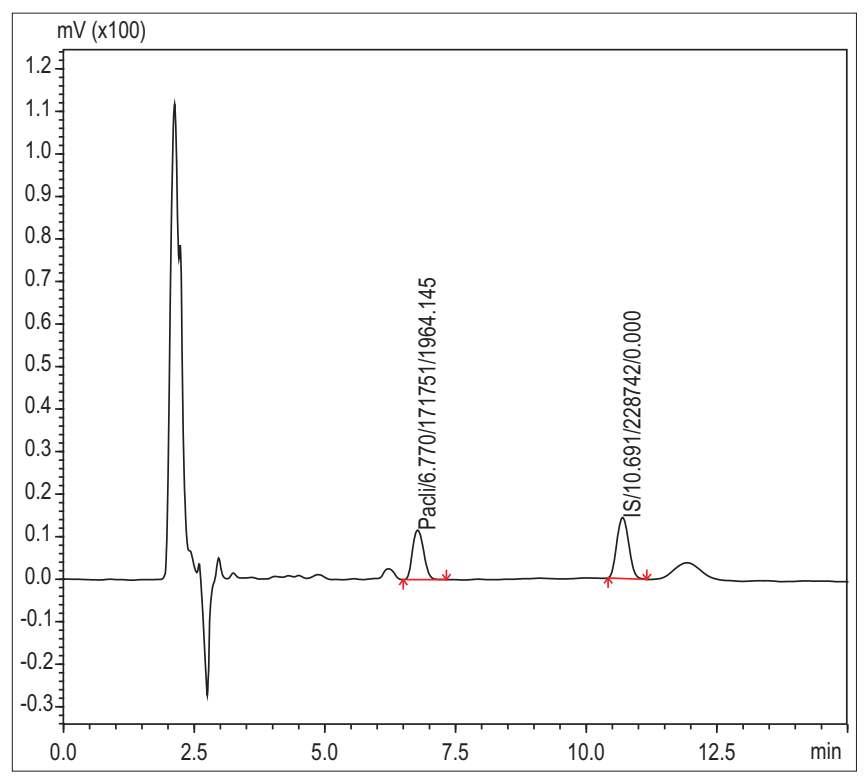

Figure 3: HPLC chromatogram patients' blood samples at $3 \mathrm{~h}$ 
paclitaxel shows nonlinear pharmacokinetics with saturable distribution and saturable elimination. ${ }^{[1,9]}$

The nonlinear pharmacokinetic behavior of paclitaxel in patients has now been well established. Both an over proportional increase in $\mathrm{Cmax}$ and a reduction in the $\mathrm{Cl}$ were found upon dosage escalation. Although this nonlinearity appears to occur with all administration schedules, it is more profound when the drug is administered within a short period of time (e.g., $3 \mathrm{~h}$ ), rather than by a lasting infusion ( 24 or $96 \mathrm{~h}$ ). These findings were thought to be consistent with saturable processes of elimination and distribution of paclitaxel, occurring when the plasma concentration of the drug is above a "saturation point." A greater than proportional increase in the area under the AUC2 and the peak plasma level (Cmax) with dosage suggests that both the elimination and the tissue distribution are saturable processes. ${ }^{[14,15]}$

Paclitaxel pharmacokinetics at different dose levels and different duration of infusions has been documented in several studies. Studies have reported that pharmacokinetic parameters such as AUC, Cmax, and clearance were not found to be different at different dose levels, indicating the nonlinear pharmacokinetic behavior. ${ }^{[16]}$ Similarly, the difference in pharmacokinetic parameters of paclitaxel (Cl, Vd, and AUC) at four dose levels were not statistically significant in this study.

In this study, the pharmacokinetic data have shown a system of saturable elimination; that is low plasma concentrations are cleared faster than high concentrations. This indicates nonlinear pharmacokinetics. Two patients at the dose of $260 \mathrm{mg}$ have shown low steady state (Css) concentrations (0.00097 and 0.00220) indicating larger clearances (89.6 and $39.5 \mathrm{l} / \mathrm{h}$, respectively). ${ }^{[9]}$ The average peak plasma concentration achieved in patients receiving $130 \mathrm{mg}$ dosage was $2 \mu \mathrm{g} / \mathrm{ml}$ which was similar to that quoted in the literature; but an increase in the dose was not associated with increased peak plasma concentrations. Elimination half-life $\left(t^{1 / 2}\right)$ of paclitaxel was found to be $2.09 \mathrm{~h}$, which is the same as quoted in the literature $(2.33 \mathrm{~h}) .{ }^{[17,18]}$

In a study by Mross on the pharmacokinetics of 3-h paclitaxel infusion, the volume of distribution at steady state ( $V$ ss) was found to be $138 \mathrm{l} / \mathrm{m}^{2}$, while in our study the value was $142 \mathrm{l} / \mathrm{m}^{2}$. This indicates a wide distribution of paclitaxel in body fluids and tissues and nearly $85 \%$ bound to plasma proteins. ${ }^{[8]}$ The elimination rate constant calculated from the equation $k=\mathrm{cl} / v(0.33)$ and from semi log graph (0.34) have shown similar values.
Peripheral neuropathy was the only adverse effect reported by most of the patients in this study. Other side effects such as hypotension, congestive heart failure, and bradycardia were not reported. Having assessed the pharmacokinetic parameters of paclitaxel, we can optimize the dose to achieve the desired plasma drug concentration to maximize the response and reduce the toxicity of the drug.

The pharmacokinetics of paclitaxel (Pacliron) in patients with different types of solid tumor has been evaluated. Four fixed doses have been used 130, 200, 230, and $260 \mathrm{mg} / \mathrm{m}^{2}$. The regimens were well tolerated by the patients.

This study is limited by the fact that the sample size was small, and the blood samples were difficult to collect at the post infusion period; however, we were able to collect blood samples at 0,1 , and $3^{\text {rd }} \mathrm{h}$ for 23 patients and post infusion samples for five patients at $5^{\text {th }}$ hour and $13^{\text {th }}$ hour.

\section{CONCLUSION}

Clinical pharmacokinetics is the application of pharmacokinetic principles to the safe and effective therapeutic management of drugs in an individual patient. Primary goals of clinical pharmacokinetics include enhancing efficacy and decreasing toxicity of a patient's drug therapy. The development of strong correlations between drug concentrations and their pharmacologic responses has enabled clinicians to apply pharmacokinetic principles to actual patient situations. To administer drugs optimally we need the knowledge of mechanism of drug absorption and also its kinetics.

In this study, paclitaxel has shown nonlinear pharmacokinetics, but the peak plasma concentrations did not increase with the dose. Further studies are required to correlate serious toxic symptoms such as myelosuppression with dose intensity.

\section{ACKNOWLEDGMENT}

The authors wish to thank Prof. M. Srinivasa Reddy, HOD, Department of Pharmaceutics, Manipal College of Pharmaceutical Sciences, Manipal, India, for giving permission to use HPLC.

\section{REFERENCES}

1. Huizing MT, Sewberath Misser VH, Pieters RC, Bokkel Huinink WW, Veenhof CH, Vermorken JB, et al. Taxanes: A new class of antitumor agents. Cancer Invest 1995;13:381-404.

2. Rowinsky EK, Donehower RC. Paclitaxel (Taxol). N Engl J Med 1995;332:1004-14.

3. Huizing MT, Keung AC, Rosing H, Van der Kuij V, Bokkel Huinink WW, 
Mandjes IM, et al. Pharmacokinetics of paclitaxel and metabolites in a randomized comparative study in platinum pretreated ovarian cancer patients. J Clin Oncol 1993;11:2127-35.

4. Sonnichsen DS, Hurwitz CA, Pratt CB, Shuster JJ, Relling MV. Saturable pharmacokinetics and paclitaxel pharmacodynamics in children with solid tumors. J Clin Oncol 1994;12:532-8.

5. Gianni L, Kearns CM, Giani A, Capri G, Vigano L, Lacatelli A, et al. Nonlinear pharmacokinetics and metabolism of paclitaxel and its pharmacokinetic/ pharmacodynamic relationships in humans. J Clin Oncol 1995;13:180-90.

6. Kearns CM, Gianni L, Egorin MJ. Paclitaxel pharmacokinetics and pharmacodynamics. Semin Oncol 1995;22:16-23.

7. Huizing MT, Giaccone G, Van Warmerdam LJ, Rosing H, Bakker PJ, Vermorken JB, et al. Pharmacokinetics of paclitaxel and carboplatin in a dose escalating and dose-sequencing study in patients with non-small-cell lung cancer. J Clin Oncol 1997;15:317-29.

8. Mross K. The pharmacokinetics of a 1-h paclitaxel infusion. Cancer Chemother Pharmacol 2000;45:463-70.

9. Rowland M. Clinical Pharmacokinetics concepts and applications. $3^{\text {rd }}$ ed. London: Lippincott Williams and Wilkins; 2000. p. 11-83.

10. Lorigan PC, Crosby T, Coleman RE. Current drug treatment guideline for epithelial ovarian cancer. Drugs 1996;51:571-84.

11. Mielke S, Sparreboom A, Behringer D, Mross K. Paclitaxel pharmacokinetics and response to chemotherapy in patients with advanced cancer treated with a weekly regimen. Anticancer Res 2005;25:4423-8.

12. Shah VP, Midha KK, Dighe S, McGilveray IJ, Byrnes JP, Skelly JB, et al. Analytical methods validation: Bioavailability, bio equivalence and pharmacokinetic studies. J Pharm Sci 1992;81:309-12.

13. Sparreboom A. Determination of paditaxel in human plasma using single solvent extraction prior to isocratic reversed-phase high-performance liquid Chromatography with ultraviolet detection. J Chromatogr B 1998;705:159-64.

14. Hurwitz CA, Relling MV, Weitman SD, Ravindranath Y, Vieni TJ, Strother DR, et al. Phase I trial of paclitaxel in children with refractory solid tumors: A Pediatric Oncology Group study. J Clin Oncol 1994;2:2324-9.

15. Schiller JH, Tutsch K, Arzoomanian R, Alberti FC, Spriggs D. Phase I trial of a 3 hour taxol infusion plus or minus granulocyte colony stimulating factor (G-CSF). Proc Am Soc Clin Oncol 1993;12:166.

16. Vinoth R. Phramacokinetics of paclitaxel administered as a 3-hour or 96-hour infusion, Pharmacol Res 1999;40:67-74.

17. Ohtsu T, Sasaki Y. Clinical pharmacokinetics and pharmacodynamics of paclitaxel: A 3-hour infusion versus a 24-hour infusion. Clin Cancer Res 1995; 1:599-606.

18. Catalin J. Assay of paclitaxel in plasma and urine by high performance liquid chromatography. J Chromatogr B 1998;709:281-8.

How to cite this article: Vasantha J, Kannan G, Goud T, Palani T, Vanitha R, Anitha R, et al. Pharmacokinetic evaluation of paclitaxel in South Indian cancer patients: A prospective study. J Young Pharmacists 2011;3:322-8.

Source of Support: Nil, Conflict of Interest: None declared.

\section{New features on the journal's website}

Optimized content for mobile and hand-held devices

HTML pages have been optimized of mobile and other hand-held devices (such as iPad, Kindle, iPod) for faster browsing speed.

Click on [Mobile Full text] from Table of Contents page.

This is simple HTML version for faster download on mobiles (if viewed on desktop, it will be automatically redirected to full HTML version)

\section{E-Pub for hand-held devices}

EPUB is an open e-book standard recommended by The International Digital Publishing Forum which is designed for reflowable content i.e. the text display can be optimized for a particular display device.

Click on [EPub] from Table of Contents page.

There are various e-Pub readers such as for Windows: Digital Editions, OS X: Calibre/Bookworm, iPhone/iPod Touch/iPad: Stanza, and Linux: Calibre/Bookworm.

\section{E-Book for desktop}

One can also see the entire issue as printed here in a 'flip book' version on desktops.

Links are available from Current Issue as well as Archives pages.

Click on $\sqrt{6}$ View as eBook 